\title{
Persepsi Nelayan Pada Daerah Penangkapan Ikan Terhadap Dampak Pembangunan Makassar Newport di Kota Makassar (Ditinjau Dalam Aspek Sosial Ekonomi)
}

\author{
Perceptions of Fishermen in The Fishing Area on The Impact of The \\ Development of Makassar Newport in Makassar City (Viewed in \\ Socio-Economic Aspects)
}

\author{
Ibnu Malkan Hasbi ${ }^{1 *}$, Sri Wulandari' ${ }^{1}$ Maryono $^{2}$ \\ ${ }^{1}$ Institute Teknologi Bisnis Maritim Balikdiwa Makassar \\ ${ }^{2}$ Politeknik Negeri Sambas
}

Info Artikel:
Diterima: 05/06/2021
Disetujui: 13/08/2021
Dipublikasi: 01/10/2021

Kata Kunci:

Persepsi Nelayan, Pembangunan Pelabuhan, Daerah Panangkapan Ikan, Dampak Sosial

\section{Keywords:}

Fishermen's Perception, Port Contruction, Fishing Area, Socio-economic Impact

*Korespondensi: ibnumalkanhasbi48@gmail.com

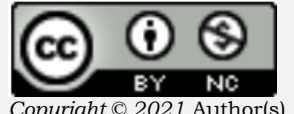

http://ojs.poltesa.ac.id/index.php/nekton

\begin{abstract}
Abstrak. Pelabuhan Makassar Newport salah satu proyek strategis Nasional untuk memperlancar arus logistik barang Proyek ini disebut nelayan menganggu jalur penangkapan dan pendapatan perahu tradisional <3 Gt. Penelitian ini bertujuan menganalisis presepsi masyarakat terhadap dampak sosial dan ekonomi pembangungan Newport. dilaksanakan pada bulan januari sampai bulan april 2021 di Kecamatan Tallo Makassar. menggunakan metode Kualitatif melalui wawancara mendalam dan observasi. Responden dalam penelitian ini sebanyak 60 orang yang bermata pencaharian sebagai nelayan. Penentuan informan dilakukan dengan snowball. Pengukuran derajat persepsi di ukur dengan metode skala likert. Hasil penelitian menunjukkan bahwa Dampak sosial nilai positif memberikan keamanan dari tindak kejahatan sedangkan nilai negatif Interaksi masyarakat kurang terjalin harmonis dan Kebersihan dari lingkungan tercemar. Dampak ekonomi hal positif yaitu Masyarakat memperoleh lahan pekerjaan sampingan sebagai mata pencaharian tambahan. nilai negatif yaitu pendapatan hasil tangkapan nelayan menurun dan biaya operasional yang harus di keluarkan lebih besar untuk melakukan aktivitas penangkapan ikan.
\end{abstract}

\begin{abstract}
Makassar Newport Port is one of the National Strategic Projects to facilitate the flow of goods logistics. This project is called fishermen disrupt fishing routes and traditional boat income $<3 \mathrm{Gt}$. This study aims to analyze public perceptions of the social and economic impacts of Newport's development. held from January to April 2021 in Tallo Makassar District. using qualitative methods through in-depth interviews and observations. respondents in this study as many as 60 people who make a living as fishermen. Determination of informants is done by snowball. Measurement of the degree of perception is measured by the Likert scale method. The results of the study indicate that the positive value of social impact provides security from crime, while the negative value of community interaction is less harmonious and clean from the polluted environment. The positive economic impact is that the community gets a side job as an additional livelihood. the negative value is that the income from fishermen's catches decreases and the operational costs that must be spent are greater to carry out fishing activities.
\end{abstract}

\section{PENDAHULUAN}

Pelabuhan perikanan sebagai lokasi kapal untuk berlabuh dan bongkar muat ikan yang dilengkapi dengan fungsi keselamatan berlayar dan fasilitas penunjang kegiatan perikanan. Pelabuhan perikanan digunakan oleh pengusaha dan pemerintahan untuk mendukung aktivitas pemanfaatan sumberdaya perikanan mulai dari persiapan produksi, produksi, pengolahan 
hasil produksi dan pemasarannya (Kurniawan et al., 2017). Fungsi pelabuhan sebagai pelayanan kegiatan transportasi laut, tempat kapal bersandar, dan bongkar muat belum di jalankannya secara maksimal sebagai lokasi strategis pelabuhan memegang peranan penting dalam perdagangan daerah. Lokasi pasar dan distribusi ikan, perbaikan layanan dan memelihara perawatan kapal perikanan, pelayanan tambat dan labuh kapal perikanan, dan pelayanan pembinaan mutu dan pengolahan hasil perikanan. Pelabuhan mempunyai peran penting di banyak negara dan wilayah dalam ekonomi (Yeo et al., 2015; Suherman et al., 2020). Pembangunan pelabuhan perikanan yang penting menunjang keberhasilan yaitu pemanfaatannya yang mempunyai dampak positif terhadap pembangunan daerah atau wilayah pesisir dan kepulauan juga meningkatkan pendapatan masyarakat pesisir yaitu nelayan (Suherman \& Dault, 2009).

Suatu wilayah dalam membangun suatu infrastruktur dengan memberi pengaruh pada peningkatan kemampuan masyarakat dalam mengelola sumber daya alam hingga peningkatan akses produktivitas yang mendorong pertumbuhan ekonomi (Sudaryadi, 2007). Infrastruktur sarana prasarana berkaitan dengan kesejahteraan sosial dan kualitas lingkungan hidup terhadap proses pertumbuhan ekonomi suatu wilayah. Sebagaimana ditunjukkan dengan indikasi bahwa wilayah yang memiliki kelengkapan sistem infrastruktur lebih baik biasanya mempunyai tingkat kesejahteraan sosial, lingkungan dan pertumbuhan ekonomi yang lebih baik pula (Permen PUPR, 2006). Keberhasilan proyek Pembangunan infrastruktur pelabuhan membutuhkan biaya yang sangat besar, dan memiliki hasil jangka panjang (Musso et al., 2006). Keberadaan pelabuhan memberikan dampak kepada ekonomi masyarakat di dalam pelabuhan perikanan, sehingga keberhasilan pelabuhan tidak hanya memberikan keuntungan bagi para investornya tetapi juga pada pemerintah melalui dan menyebar pada kawasan perekonomian (Ho \& Ho, 2006).

Peran penting dan strategis suatu pelabuhan dalam aktivitasnya sangat besar disumbangkan bagi pertumbuhan industri, ekonomi dan perdagangan serta merupakan bidang usaha yang memberikan kontribusi bagi pembangunan ekonomi nasional. Hal ini membawa konsekuensi terhadap pengelolaan bidang usaha operasi pelabuhan dapat dilakukan dengan cara efektif, dan efisien sehingga pelayanan pelabuhan menjadi aman, lancer dan cepat dengan biaya yang terjangkau. Pelayanan yang diberikan untuk pelabuhan yaitu pelayanan kapal terhadap muatan yaitu barang dan penumpang (Gultom, 2017).

Menurut Hutubessy et. al. (2019) persepsi nelayan terhadap perubahan hasil tangkapan menunjukkan bahwa penyebabnya yaitu sampah, kekeruhan, kerusakan karang, minyak dan berkurangnya karang berdampak pada berkurangnya hasil tangkapan, bahkan beberapa nelayan menyatakan 
ikan tidak ada lagi, sehingga nelayan harus menempuh jarak yang jauh untuk dapat menangkap ikan.

Pembangunan pelabuhan laut tentunya berkaitan dengan kehidupan masyarakat pesisir. Menurut Satria (2004) dalam Muswar (2011), kelompok masyarakat hidup dalam kelompok sosial berdomisili wilayah kepulauan dan pesisir. Mempunyai kebudayaan khas bergantung pada pendayagunaan sumberdaya pesisir disebut masyarakat pesisir, yang tentunya tidak hanya nelayan tetapi juga pembudidaya ikan bahkan pedagang. Perencanaannya pembangunan Pelabuhan Makassar New Port memiliki beberapa tujuan salah satunya untuk meningkatkan kondisi sosial ekonomi masyarakat pesisir di sekitar pelabuhan Makassar New Port. Penelitian ini di laksanakan untuk menganalisis presepsi masyarakat dengan melihat dampak sosial dan dampak ekonomi dari pembangunan sebelum dan sesudah adanya pelabuhan Newport.

\section{METODE PENELITIAN}

Penelitian ini akan di lakukan pada bulan Januari hingga bulan April 2021 kelurahan Kaluku Bodoa, buloa Tallo dan cambayya untuk melihat persepsi nelayan terhadap dampak pembangunan Makassar Newport. Lokasi Penelitian di pilih berdasarkan karateristik Masyarakat yang sebagian besar yaitu nelayan tradisional yang menggantungkan hidupnya baik dari segi sosial dan ekonomi. Metode Penelitian yang di gunakan kualitatif. Penelitian kualitatif seara realita yaitu ditekankan terbangun secara sosial, hubungan erat antara peneliti dan subjek yang diteliti (Denzin \& Lincoln, 2011). Penentuan sampel dengan metode snowball sampling untuk mengidentifikasi informan yang berprofesi sebagai nelayan. Pengumpulan data di lakukan melalui observasi dan wawancara mendalam kepada informan. komponen analisis data menggunakan model analisis yang mencakup pemilihan data, observasi, penyajian data dan penarikan kesimpulan atau verifikasi data.

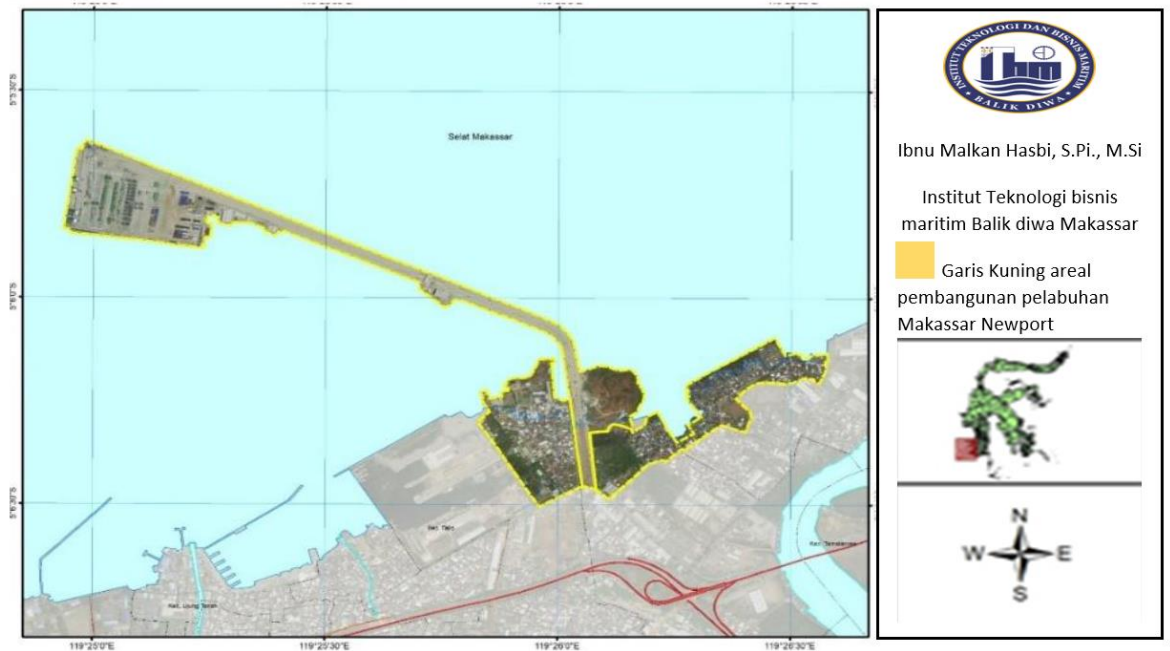

Gambar 1. Peta Lokasi Penelitian 
Analisis yang di gunakan adalah perhitungan skala likert untuk mendeskripsikan presepsi nelayan terhadap dampak sosial ekonomi pembangunan Pelabuhan Makassar Newport. Analisis ini di gunakan untuk mengukur pendapat, dan persepsi seseorang maupun sekelompok orang tentang fenomena sosial. variabel yang akan diukur dijabarkan menjadi indikator variabel. Kemudian indikator variabel tersebut dijadikan sebagai titik tolak untuk menyusun item-item instrument yang dapat berupa pertanyaan atau pernyataan (Umar, 2011). Adapun rumus yang di gunakan sebagai berikut :

$$
\text { Rumus Index } \%=\frac{\text { Total Skor }}{y} * 100
$$

Total skor $=$ Total jumlah responden yang memilih $\mathrm{Y}=$ Skor tertinggi (skala Likert $\mathrm{x}$ jumlah responden)

Dengan bobot penilaian Skala Likert sebagai berikut (Sugiono, 2012).

Tabel 1. Bobot Penilaian Skala Likert

\begin{tabular}{ccc}
\hline Skor & Kode & Keterangan \\
\hline 5 & SS & Sangat Setuju \\
4 & S & Setuju \\
3 & N & Netral \\
2 & TS & Tidak Setuju \\
1 & STS & Sangat Tidak Setuju \\
\hline
\end{tabular}

Teknik pengumpulan data dengan menggunakan Kuesioner. Kuisioner sebagai pertanyaan tertulis yang akan dijawab oleh responden penelitian, agar peneliti memperoleh data lapanganyang di peroleh untuk memecahkan masalah penelitian yang ada terjadi di lapangan (Supardi, 2015:127). Pertanyaan yang diajukan menggunakan skala likert dapat dihitung sebagai jawaban-jawaban dari responden tersebut dapat diberi bobot nilai atau skor likert dalam bentuk kualitatif dan kuantitatif.

Tabel 2. Kriteria Interpretasi Persepsi Masyarakat

\begin{tabular}{l} 
Kriteria Interpretasi \\
\hline Angka $0 \%-20 \%=$ Sangat Lemah \\
Angka $21 \%-40 \%=$ Lemah \\
Angka $41 \%-60 \%=$ Cukup \\
Angka $61 \%-80 \%=$ Kuat \\
Angka $81 \%-100 \%=$ Sangat Kuat
\end{tabular}

Bobot penilaian di atas untuk mengukur persepsi masyarakat mengenai tingkat kepuasan nelayan dengan pembangunan pelabuhan Newport terhadap dampak sosial dan ekonomi yang ada pada masyarakat. 


\section{HASIL DAN PEMBAHASAN}

Salah satu Proyek Strategis Nasional (PSN) Makassar Newport di Kawasan Indonesia Timur terletak pada $119^{\circ} 23^{\prime} 40^{\prime \prime}$ BT dan 119²6'30" BT serta $05^{\circ} 05^{\prime} 30^{\prime}$ LS dan 05 06'45”LS. Pelabuhan ini beroperasi sejak tahun 2019 pada pembangunan fasilitas pelabuhan, fasilitas umum dan jalan akses. Selanjutnya, pada tahap II, kegiatan pengembangan akan difokuskan untuk pembangunan kawasan industry dan kawasan bisnis. Dalam jalur pelayaran internasional, lokasi Makassar New Portsangatlah strategis. Pelabuhan yang nantinya akan memiliki jalur transportasi terintegrasi ini berada di jalur pelayaran Australia-Indonesia. Development Area (AIDA) dan Brunei, Indonesia, Malaysia, Philippina East Asian Growth Area (BIMP EAGA) serta untuk jalur Asia Pasifik. Makassar New Portini diharapkan menjadi hub untuk Indonesia dibagian timur, sehingga pengiriman barang tak perlu lagi melalui Pelabuhan Tanjung Priok Jakarta atau Tanjung Perak Surabaya.

Fokus Penelitian ini yaitu melihat presepsi masyarakat terrhadap dampak sosial dan dampak ekonomi dari pembangunan pelabuhan Makassar Newport.

Tabel 3. Dampak Sosial Masyarakat terhadap pembangunan Pelabuhan Makassar Newport

\begin{tabular}{|c|c|c|c|c|}
\hline \multirow{2}{*}{ No } & \multirow{2}{*}{ Pernyataan } & \multirow{2}{*}{ Indikator } & \multicolumn{2}{|c|}{ Responden } \\
\hline & & & Skor & Presentase \\
\hline \multirow[t]{5}{*}{1} & Interaksi Masyarakat & SS & 5 & $6,32 \%$ \\
\hline & tetap terjalin harmonis & $\mathrm{S}$ & 15 & $18,98 \%$ \\
\hline & sejak adanya & $\mathrm{KS}$ & 30 & $37,97 \%$ \\
\hline & pembangunan & TS & 26 & $32,91 \%$ \\
\hline & $\begin{array}{l}\text { pelabuhan Makassar } \\
\text { Newport }\end{array}$ & STS & 3 & $3,80 \%$ \\
\hline \multirow[t]{5}{*}{2} & Keamanan Masyarakat & SS & 25 & $23,58 \%$ \\
\hline & dari aksi pencurian dan & $\mathrm{S}$ & 48 & $45,28 \%$ \\
\hline & tindak kejahatan pada & KS & 24 & $22,64 \%$ \\
\hline & pemukiman & TS & 8 & $7,50 \%$ \\
\hline & masyarakat & STS & 1 & $1 \%$ \\
\hline \multirow[t]{5}{*}{3} & Kebersihan Limbah & SS & 5 & $6,02 \%$ \\
\hline & dari pelabuhan tidak & $\mathrm{S}$ & 24 & $28,91 \%$ \\
\hline & mencemari lingkungan & $\mathrm{KS}$ & 30 & $36,14 \%$ \\
\hline & sekitar & TS & 22 & $26,50 \%$ \\
\hline & & STS & 2 & $2,40 \%$ \\
\hline
\end{tabular}

\section{Interaksi Masyarakat}

Interaksi Masyarakat dapat berupa bentuk persaingan , kerjasama dan juga dapat berbentuk pertentangan. Suatu pertentangan mendapatkan suatu Penyelesaian dan dapat menemukan jalan keluar dan berhasil di atasi akan besar peranannya dalam mencapai target. 


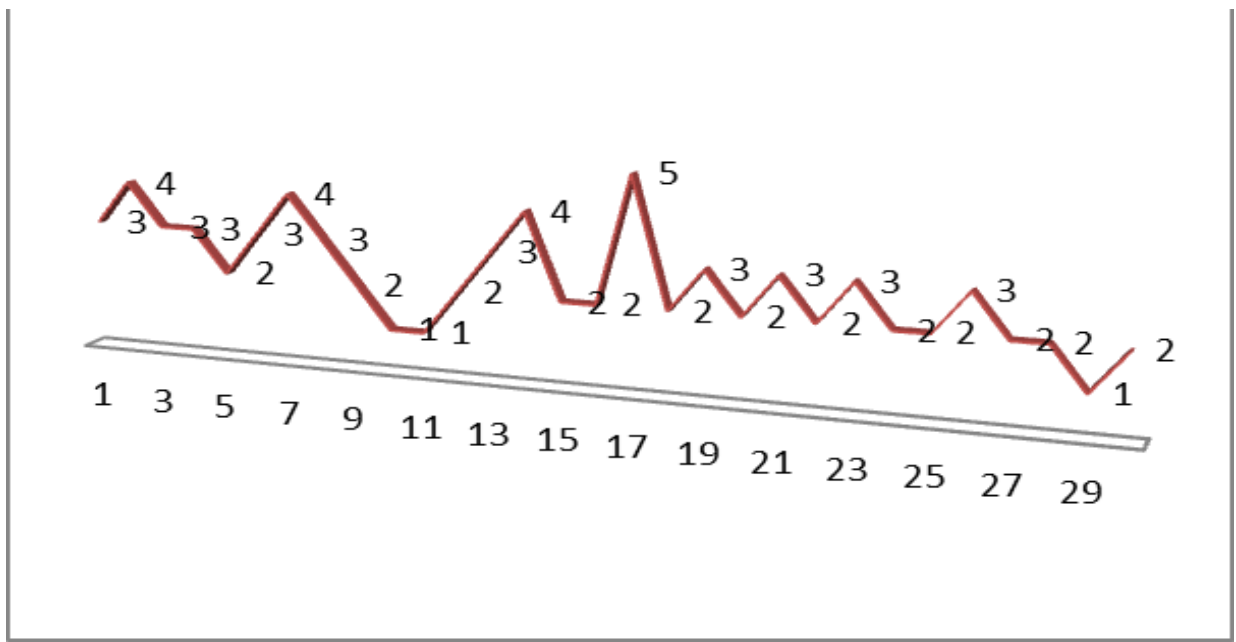

Gambar 2. Interaksi Masyarakat

Pada Gambar di atas dapat di lihat bahwa presepsi tentang interaksi masyarakat menyatakan kurang setuju setuju dengan presentase 37,97 persen. Hal ini disebabkan karena masyarakat terganggu oleh suara bising dari berbagai aktivitas yang terjadi di dalam pelabuhan Makassar Newport sehingga tidak terjadi keharmonisan masyarakat yang bermukim di daerah tersebut.

Menurut Soekanto (2002 : 15) interaksi sosial sebagai hubungan sosial yang menyangkut hubungan antara orang dan individu antara individu dan kelompok, kelompok dan kelompok manusia. Manusia berinteraksi dengan sesamanya dalam kehidupan untuk menghasilkan Interaksi manusia dalam suatu kelompok sosial. Bertemunya individu secara langsung tidak akan menghasilkan pergaulan hidup dalam meniptakan suatu kelompok sosial. Hubungan ini akan terjadi apabila orang perorangan atau kelompok masyarakat bekerja sama, saling berbicara, untuk mencapai suatu tujuan bersama, mengadakan persaingan, dan sebagainya. Interaksi masyarakat meniptakan hubungan sosial terhadap kelompok - kelompok manusia terjadi antara kelompok tersebut sebagai suatu kesatuan dan pribadi anggota anggotanya. Interaksi sosial antara kelompok - kelompok manusia terjadi pula di dalam hubungan sosial.

\section{Keamanan}

Presespsi Masyarakat terhadap Keamanan yang ada pada sekitar pelabuhan menunjukkan setuju dengan presentase $45,25 \%$ bahwa keamanan di sekitar pelabuhan kurang dari aksi pencurian dan tindak kejahatan. Hal ini di sebabkan karena adanya satpam dan Polsek yang bertugas pada areal pelabuhan Sehingga masyarakat merasa aman. Pelabuhan yang terlindungi oleh lidah pantai dan perlindungan buatan dan 
NEKTON, Vol 1 No 2 Oktober 2021: hal 72 - 83

keamanan pada alur masuk pelabuhan dan terdapat fasilitas yang melayani dan menghindari pengunjung dari tindah kejahatan (Arif et al., 2020).

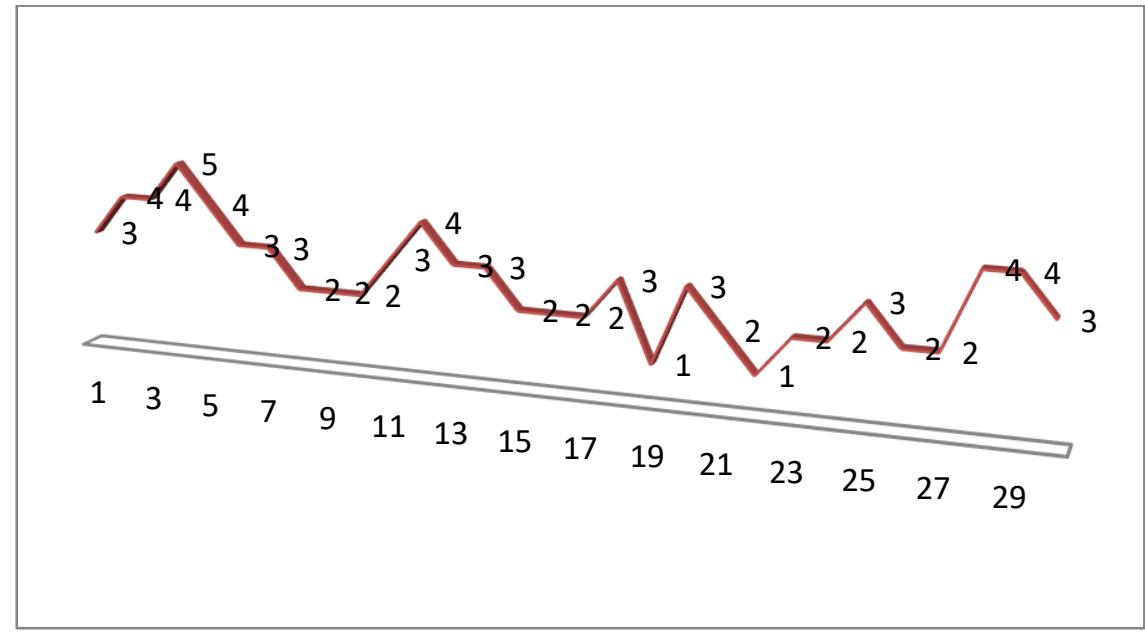

Gambar 3. Keamanan

\section{Kebersihan Lingkungan}

Pada gambar 4 menunjukkan bahwa presepsi masyarakat terhadap kebersihan lingkungan menunjukkan kurang setuju dengan presentase 36,14 persen. Menurut sebagian besar responden menyatakan bahwa perairan di sekitar pemukiman masyarakat tercemar akibat limbah pembuangan dari kapal-kapal yang bersandar pada pelbuhan Makassar Newport.

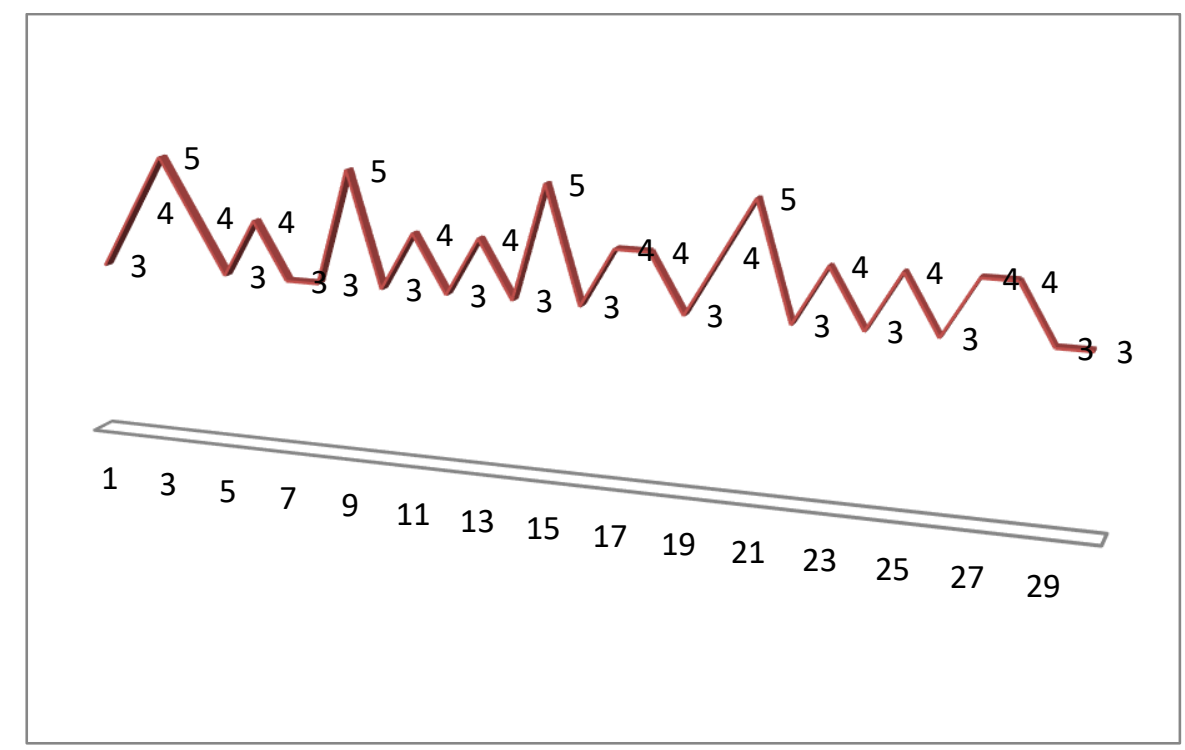

Gambar 4. Kebersihan Lingkungan

Di dalam pembangunan pelabuhan perikanan harus menerapkan amdal untuk menghindari pencemaran dan mempertimbangkan arus penumpang dan barang di kemudian hari. 
NEKTON, Vol 1 No 2 Oktober 2021: hal 72 - 83

Tabel 4. Dampak Ekonomi Masyarakat Terhadap Pembangunan Pelabuhan Makassar Newport

\begin{tabular}{llccc}
\hline \multirow{2}{*}{ No } & \multicolumn{1}{c}{ Pernyataan } & Indikator & \multicolumn{2}{c}{ Responden } \\
\cline { 2 - 5 } & Pendapatan nelayan & SS & 0 & Presentase \\
\cline { 2 - 5 } & meningkat dengan & S & 12 & $0 \%$ \\
& berdirinya pelabuhan & KS & 24 & $17,39 \%$ \\
& Makassar Newport & TS & 28 & $34,78 \%$ \\
& & STS & 5 & $40.57 \%$ \\
\hline 2 & Lahan Kerja & SS & 25 & $22,96 \%$ \\
& Sampingan sebagai & S & 48 & $44 \%$ \\
& mata pencaharian & KS & 33 & $30,27 \%$ \\
& tambahan & TS & 2 & $1,83 \%$ \\
masyarakat sekitar & STS & 1 & $0,93 \%$ \\
\hline Biaya Operasional yang & SS & 5 & $6,57 \%$ \\
di gunakan nelayan & S & 8 & $10,52 \%$ \\
untuk menangkap ikan & KS & 33 & $43,42 \%$ \\
menurun sejak & TS & 28 & $36,84 \%$ \\
pelabuhan Makassar & STS & 2 & $2,63 \%$ \\
Newport beroperasi & & & \\
\hline
\end{tabular}

\section{Pendapatan}

Pada gambar 5 bahwa presepsi tidak setuju terhadap pendapatan Nelayan meningkat sejak berdirinya pelabuhan Makassar Newport dengan presentase 40,57 persen. Hal ini terjadi karena sulitnya memperoleh ikan pada area perairan tersebut. Dampak pencemaran dan pembangunan pelabuhan tersebut mengakibatkan pendapatan nelayan berkurang (Yusuf et al., 2005). Sehingga masyarakat perlu ke laut lepas untuk memperoleh pendapatan yang besar (Pratama et al., 2019).

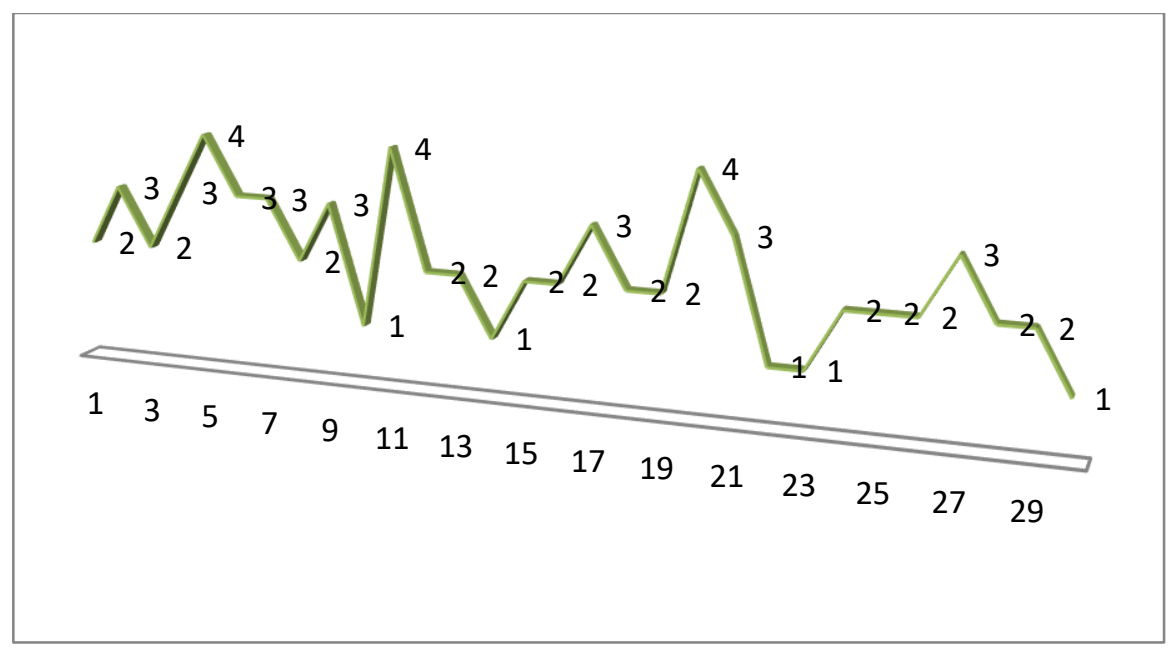

Gambar 5. Pendapatan Nelayan 
Setelah reklamasi volume tangkapan terbesar diperoleh sebesar 2160 $\mathrm{kg}$ per tahun dan volume tangkapan yang terkecil diperoleh sebesar $1080 \mathrm{~kg}$ per tahun, dengan rata-rata volume tangkapan sebesar $1476 \mathrm{~kg}$ per tahun. Ikan yang paling sering dan paling banyak ditangkap masih sama yaitu ikan gamasi. Terjadi perubahan setelah reklamasi, hasil tangkapan menjadi berkurang. Hal ini dikarenakan lahan untuk menangkap ikan menjadi berkurang dan juga jauh (Monita et al., 2020).

\section{Lahan Kerja Sampingan}

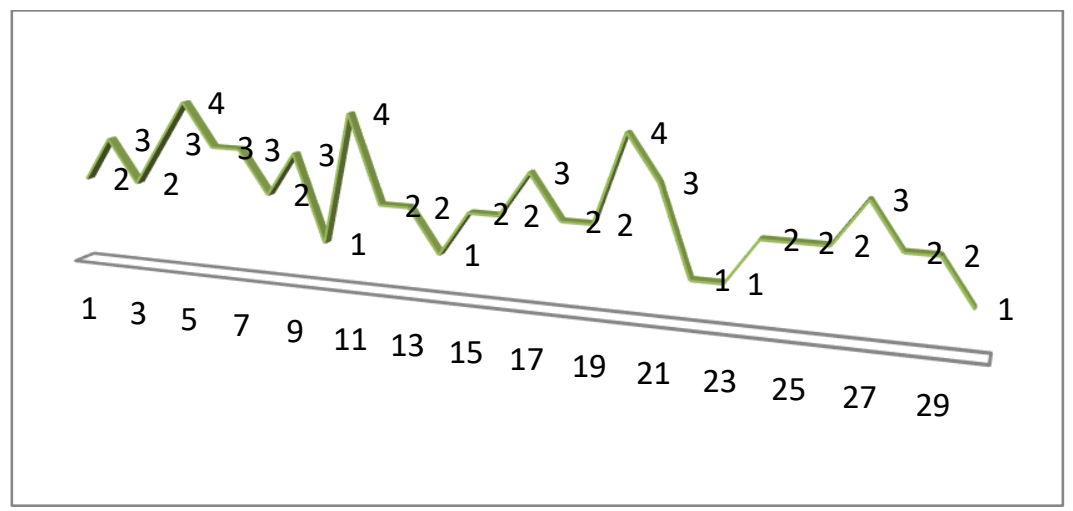

Gambar 6. Lahan Kerja Sampingan

Presepsi Masyarakat terhadap lahan pekerjaan sampingan di pelabuhan Makassar Newport menunjukkan setuju dengan presentase 44\% dominan. Dari hasil wawanara responden menunjukkan bahwa sebagian masyarakat mendapatkan pendapatan tambahan dari kegiatan parkir, petugas kebersihan dan beberapa aktivitas lain pada pelabuhan tersebut. Fasilitas pelataran (Taman) Parkir menambah pendapatan tambahan masyarakat atau bangunan gedung pelabuan di batasi dengan garis berwarna putih dan kuning terletak di samping dan depan pembatas pelabuhan (Silviana \& Limi, 2020).

\section{Biaya Operasional}

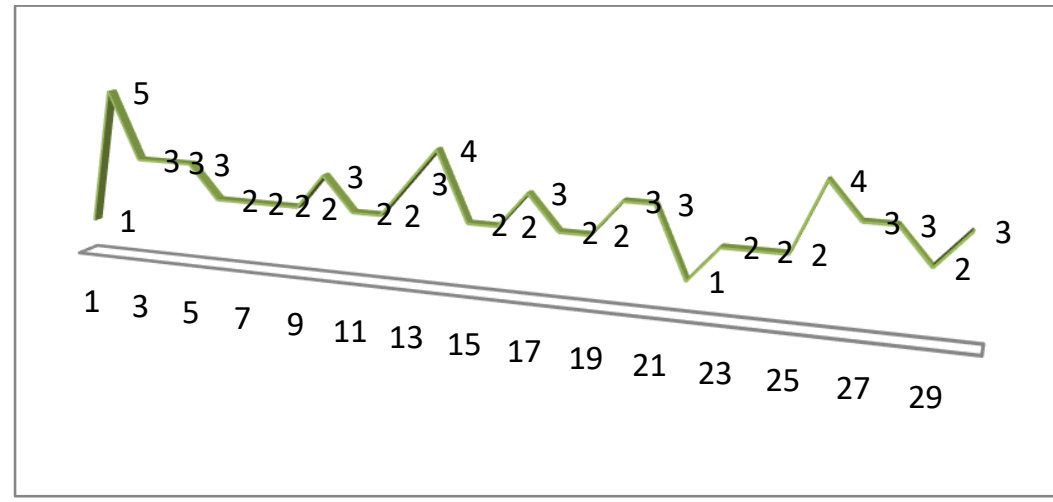

Gambar 7. Biaya Operasional 
Pada gambar 7 bahwa presepsi masyarakat terhadap menurunnya biaya operasional yang di keluarkan nelayan untuk menangkap ikan pada area tersebut menyatakan kurang setuju dengan presentase 43,42 persen. Hal ini di sebabkan karena Nelayan harus menempuh jarak jauh untuk sampai ke lokasi fishing ground, pembangunan dermaga di sepanjang garis pantai membuat masyarakat yang berprofesi nelayan harus mengeluarkan biaya operasional bahan bakar solar lebih besar dari sebelumnya untuk mengelilingi areal tersebut. Menurut modul tataruang kawasan reklamasi pantai (2007) pada dasarnya reklasmasi perlu memperhatikan aktivitas nelayan dan kebutuhan pengembangan kawasan budidaya yang ada di sisi pantai. Pembangunan harus memperhatikan tata ruang, studi kelayakan pelabuhan.

\section{KESIMPULAN}

Pembangunan Pelabuhan Makassar Newport di Makassar memberikan dampak Sosial pada masyarakat sekitar pelabuhan. Dari hasil presepsi masyarakat menunjukkan bahwa nilai positif memberikan keamanan dari aksi tindak kejahatan pada pemukiman masyarakat dengan presentase 45,28 persen menujukkan cukup. sedangkan nilai negative menunjukkan interpretasi Interaksi masyarakat kurang terjalin harmonis dan Kebersihan lingkungan yang teremar dari limbah laut menunjukkan interpretasi 26,50 persen masyarakat ketegori lemah.

Dampak Ekonomi masyarakat terhadap pembangunan pelabuhan Makassar Newport dari hasil presepsi dari masyarakat memiliki nilai positif yaitu Masyarakat memperoleh lahan pekerjaan sampingan sebagai mata pencaharian tambahan menujukkan presentase 44 persen menunjukkan interpretasi keperayaan masyarakat cukup Sedangkan nilai negatif yaitu Pendapatan hasil tangkapan nelayan menurun dan biaya operasional/modal yang harus di keluarkan lebih besar untuk melakukan aktivitas penangkapan ikan, menunjukkan interpretasi 26,50 persen masuk ketegori lemah.

\section{DAFTAR PUSTAKA}

Arif, M., Purwangka, F., \& Muninggar, R. (2020). Analisis Risiko Perencanaan Industri Pengolahan Ikan di Pelabuhan Perikanan Samudera (PPS) Kutaraja. Akuatika Indonesia, 5(2), 55. https://doi.org/10.24198/jaki.v5i2.27635

Denzin, N. K., \& Lincoln, Y. S. (Eds.). (2011). The Sage handbook of qualitative research. Sage.

Gultom, E. (2017). Pelabuhan Indonesia sebagai Penyumbang Devisa Negara dalam Perspektif Hukum Bisnis. Kanun: Jurnal Ilmu Hukum, 19(3), 419444. https://doi.org/10.24815/kanun.v19i3.8593

Ho, M. W., \& Ho, K. H. (2006). Risk Management in Large Physical Infrastructure Investments: The Context of Seaport Infrastructure 
Development and Investment. Maritime Economics \& Logistics, 8(2), 140168. https: / / doi.org/10.1057/palgrave.mel.9100153

Hutubessy, B. G., Silooy, F., Tupamahu, A., Siaheinenia, S., Pailin, J. B., \& Tawari, R. H. S. (2019). Profil dan Persepsi Nelayan Terhadap Perubahan Hasil Tangkapan Ikan Perairan Pantai di Teluk Ambon. Jurnal Enggano, 4(1), 43-51. https: / / doi.org/10.31186/jenggano.4.1.43-51

Kurniawan, F., Triarso, I., \& Kurohman, F. (2017). Analisis tingkat kepuasan nelayan terhadap fungsi Pelabuhan Perikanan Nusantara Pekalongan berdasarkan peraturan menteri kelautan dan perikanan nomor per.08/Men/2012. Journal of Fisheries Resources Utilization Management and Technology, 6, 1-10.

Monita, R., Triarso, I., \& Kurohman, F. (2020). Journal of Fisheries Resources Utilization Management and Technology. 9(4), 21-32.

Muswar, H.S. (2011). Dampak Pelabelan Ramah Lingkungan (ecolabeling) terhadap Nelayan Ikan Hias(Kasus: Nelayan Ikan Hias Desa Les, Kec. Tejakula, Kab. Buleleng, Bali). Skripsi. Institut Pertanian Bogor. Bogor.

Musso, E., Ferrari, C., \& Benacchio, M. (2006). Port Investment: Profitability, Economic Impact and Financing. Research in Transportation Economics, 16, 171-218. https://doi.org/10.1016/S0739-8859(06)16008-4

Peraturan Menteri Pekerjaan Umum dan Perumahan Rakyat Nomor 30 Tahun 2006 Pedoman Teknis Fasilitas dan Aksesibilitas pada Bangunan Gedung dan Lingkungan. 1 Desember 2006. Lembaran Negara Republik Indonesia Tahun 2006 Nomor 30. Jakarta.

Pratama, D., Wijayanto, D., \& Jayanto, B. B. (2019). Valuasi Ekonomi Dampak Keberadaan PPN Brondong Lamongan, Jawa Timur. Journal of Entomology and Zoology Studies, 8(1), 10-17. https://ejournal3.undip.ac.id/index.php/jfrumt/article/view/28613/24 418

Silviana, S., \& Limi, M. A. (2020). Dampak Pelabuhan Perikanan Samudera Kendari terhadap Kondisi Sosial Ekonomi Masyarakat Nelayan di Kecamatan Abeli Kota Kendari. JIA (Jurnal Ilmiah Agribisnis): Jurnal Agribisnis Dan Ilmu Sosial Ekonomi Pertanian, 5(1), 35. https://doi.org/10.37149/jia.v5i1.9214

Soekanto, S. (2002). Sosiologi Suatu Pengantar Ringkas. Jakarta: CV Rajawali.

Sudaryadi. (2007). Dampak Pembangunan Jalur Jalan Lintas Selatan Terhadap Output Sektor Produksi Rumah Tangga Jawa Tengah (Simulasi SNSE Jawa Tengah 2004). Tesis. Program Pasca Sarjana Universitas Diponegoro, Semarang.

Suherman, A., Boesono, H., Kurohman, F., \& Muzakir, A. K. (2020). Kinerja Pelabuhan Perikanan Nusantara (Ppn) Karangantu - Banten, Indonesia. Depik, 9(2), 344-355. https://doi.org/10.13170/depik.9.2.17457

Suherman, A., \& Dault, A. (2009). Analisis Dampak Sosial Ekonomi Keberadaan Pelabuhan Perikanan Nusantara Brondong Lamongan Jawa Timur. Jurnal Saintek Perikanan, 5(1), 25-30. http: / / eprints.undip.ac.id/16931/

Supardi. (2015). Penilaian Autentik. Jakarta: Raja Grafindo Persada.

Umar, H. (2011). Metode Penelitian Untuk Skripsi dan Tesis Bisnis Edisi 11. Jakarta: PT Raja Grafindo Persada. 
Yeo, G. T., Thai, V. V., \& Roh, S. Y. (2015). An Analysis of Port Service Quality and Customer Satisfaction: The Case of Korean Container Ports. Asian Journal of Shipping and Logistics, 31(4), 437-447. https://doi.org/10.1016/j.ajs1.2016.01.002

Yusuf, H., Moedikdjo, K., Saeni, M. S., \& Nasution, L. I. (2005). Dampak Pembangunan Pelabuhan Perikanan Terhadap Penyerapan Tenaga Kerja dan Pendapatan Masyarakat (Studi Kasus di Pelabuhan Perikanan Lempasing, Bandar Lampung). VI(1), 57-64. 